\title{
Majdan Nezalezjnosti: symbolikk og funksjon
}

\author{
Arve Hansen ${ }^{\star}$ \\ PhD-stipendiat, Universitetet i Tromsø - Norges arktiske universitet
}

\begin{abstract}
Much has been said and written about the Ukrainian revolution of 2013-14, yet research on Maidan Nezalezhnosti, the protests' most iconic location, has thus far been rather limited. This article analyses the history, attributes and symbolism of this particular city space. What function does Maidan have in the Ukrainian society? In the cause of my fieldwork in Kyiv 2013-15 on the recent revolution, I found that Maidan has many features that make it a particularly suitable site for protests. In the current article I argue that several factors related to the square's physical space, from its location between the religious, historical and political centres of Ukraine, to its proximity to important landmarks, as well as its infrastructure, shape, architecture, and size, make Maidan both a symbolic and a practical space to occupy for people demanding change. Since the collapse of the Soviet Union Maidan has acquired a special significance for Ukrainians. The name of the square itself could be interpreted as a protest against Russia, and the many protests and three revolutions on Maidan have given it a particular revolutionary meaning. I argue that Maidan functions as a socio-political safety valve - a place people turn to and turn up at to demand change when the formal political institutions fail to deliver.
\end{abstract}

Keywords: City space, Independence square, Maidan, protests, revolution, Ukraine

I sentrum av den ukrainske hovedstaden Kyiv ligger Majdan Nezalezjnosti Uavhengighetsplassen - et av Kyivs større byrom. ${ }^{1}$ Majdan fikk mye oppmerksomhet under Euromajdan-protestene vinteren 2013-14 som etter tre dramatiske måneder endte med minst 82 drepte demonstranter (Helseministeriet i Ukraina 2014) og et maktskifte i landet. Protestene ble også opptakten til krisen på Krimhalvøya og krigen i Donbas. Så langt har krigen krevet over 9100 menneskeliv (UN News Centre 2015), mens 1,38 millioner er internt fordrevet (UNHCR 2015a) og 1,1 millioner har flyktet fra landet (UNHCR 2015b: 2).

I mitt feltarbeid i Kyiv mellom november 2013 og mai 2015, hvor jeg undersøkte drivkreftene bak protestene, var det flere ting som tydet på at Uavhengighetsplassen

^Kontaktinformasjon: Arve Hansen. Email: arve.hansen@uit.no

${ }^{1}$ I denne artikkelen benytter jeg meg av den ukrainske formen av ukrainske egennavn (Kyiv, Donbas, Janukovytsj), ikke den russiske (Kiev, Donbass, Janukovitsj) (i samsvar med Norsk språkråd 2014). Alle egennavn er transliterert i henhold til språkrådets anbefalinger. Ukrainsk: VL 24.10.6 (Norsk språkråd u.d. b). Russisk: VL 6.2.05 (Norsk språkråd u.d. a). 
hadde en viktig symbolsk betydning for ukrainere. Det tydeligste eksempelet på dette var at protestene tok Euromajdan som navn - en kombinasjon av ordene Europa og Majdan. Men det er kanskje enda mer illustrerende at opprørspolitiets første angrep på demonstrantene i Kyiv, som fant sted natt til 30. november 2013 og førte til at mange ukrainere begynte å støtte protestene (Hansen 2015: 44-45), ble omtalt som Angrepet på Majdan (Rozhin Majdanu). ${ }^{2}$ Det var også interessant å se at Majdan som begrep ikke var låst til det fysiske byrommet på Uavhengighetsplassen, men ble en samlebetegnelse for alle områdene okkupert av de protesterende: Det dukket opp såkalte lokale majdan-er også i andre ukrainske byer. En respondent, lokalhistorikeren Serhij, beskriver Majdan som noe bevegelig: «Etter angrepet på Majdan (...) [dukket det opp] et morsomt uttrykk: 'Majdan har flyttet til Mykhajlivskaplassen' (...) det vil si at Majdan ikke er knyttet til plassen, den er allerede en protestaksjon. Det er ikke viktig hvor den er.» ${ }^{3}$

Selv om mye av den internasjonale oppmerksomheten nå har flyttet fra Kyiv til Donbas, blir Majdan fremdeles diskutert i Ukraina. I forbindelse med president- og parlamentsvalgene i 2014 og før lokalvalget i oktober 2015, truet opposisjonelle partier og grupperinger med «å gå ut på Majdan» om Porosjenko-administrasjonen ikke får slutt på krigen og fart på reformvirksomheten. Myndighetene har på sin side prøvd å vise at symbolikken rundt Majdan er viktig for dem, og arrangerte sommeren 2015 en stor arkitektkonkurranse for å rekonstruere byrommet, med store midler stilt til rådighet - til tross for en vaklende økonomi (Terra Dignitas 2015). Blant annet ble det diskutert hvordan minnesmerket for Euromajdan og de falne demonstrantene skal se ut.

For å forstå de omveltningene som foregikk i Kyiv i februar 2014 og dermed bakgrunnen for de begivenhetene som nå utspiller seg i landet, er det nødvendig å se nærmere på hva Majdan betyr for ukrainere. Hva er det som gjør at protester oppstår på Uavhengighetsplassen? Hva symboliserer Majdan? Hvilke funksjoner har plassen i det ukrainske samfunnet?

Jeg har av plasshensyn begrenset artikkelen til å handle om protester i Kyiv, og sammenhengen mellom dem og byrommet de oftest arrangeres i. Jeg vil derfor ikke analysere andre byrom, eller å gå inn på de enkelte protestaksjonenes struktur eller organisering.

Denne artikkelen er inndelt i tre deler: Først ser jeg på Uavhengighetsplassens fysiske utforming, posisjon, lokalhistorie og daglig bruk. Deretter diskuterer jeg symbolikken knyttet til Majdan. Til slutt diskuterer jeg hvilke funksjoner Majdan har i det ukrainske samfunnet i dag.

\footnotetext{
${ }^{2}$ Rozhin kan oversettes med spredning, bortjaging, rydding, storming eller angrep. Siden en plass verken kan spres eller jages bort, «Ryddingen av Majdan» ikke fanger alvorlighetsgraden av det som skjedde, og «Stormingen av Majdan» ble brukt om politiets storming av plassen 18.-19. februar 2014, har jeg valgt å omtale hendelsen som et angrep.

${ }^{3}$ «Posle razgona Majdana (...) byla takaja fraza smesinaja: 'Majdan peremestilsja na Mikhajlovskuju plosjtsjad (...) polutsjajetsia, sjto Majdan ne privjazan k plosjtsjadi - eto uzje protestnaja aktsija. Ne vazjno gde on.»
} 
Jeg argumenterer for at Uavhengighetsplassen har blitt et naturlig sted å protestere, som til tross for et par ulemper, egner seg godt for store folkemengder. Samtidig har Majdan en spesiell symbolsk betydning som folkets plass - et sted assosiert med flere revolusjoner og det eneste stedet folket føler de har direkte innflytelse på landets politikk. Mine funn støtter ideen om at Majdan i dag fungerer som en sosio-politisk sikkerhetsventil i et dysfunksjonelt og korrupt politisk system.

\section{Metoder og teori}

I analysen av Majdans fysiske utforming har jeg basert meg på egne observasjoner i Kyiv mellom november 2013 og juli 2015. ${ }^{4}$ Det teoretiske grunnlaget for analysen har vært Lynch' (1960) teorier om byers funksjonalitet og betydning. ${ }^{5}$ I løpet av revolusjonen utførte jeg 23 befaringer på Majdan, og jeg fikk kontakt med mange mennesker. Av disse valgte jeg ut seks respondenter til syv semistrukturerte dybdeintervjuer. I denne artikkelen benytter jeg meg av utdrag fra disse intervjuene. ${ }^{6}$ Siden jeg har hatt to lengre opphold i Kyiv (fra januar til juni 2011, og fra juli 2013 til desember 2015) og jevnlig reist til byen (fra mai 2007), har jeg også mange personlige erfaringer fra byen. Disse refererer jeg til som egne erfaringer.

I forskningslitteraturen finnes det inngående analyser av forholdet mellom demokrati, protester og enkelte byrom (se Parkinson 2012). Mer konkret har Occupy-bevegelsens forhold til okkuperte byrom i vestlige byer blitt analysert (Hammond 2013); parken som ble okkupert av Gezi-park-protestene i Istanbul i 2013 har blitt drøftet (Göle 2013a, 2013b; Inceoglu 2014, 2015; Örs 2014); og det samme gjelder flere av protestene i byrom under Den arabiske våren fra 2011 (se for eksempel Lopes de Souza \& Lipietz 2011), protestene på Den himmelske freds plass i 1989 (Hershkovitz 1993; Lee 2009), og så videre. Det er imidlertid gjort få analyser av byrom i forbindelse med protester i Kyiv. Mens det har vært analyser av Uavhengighetsplassens utforming og historie, som Hrysjtsjenkos (2013) drøfting av byrommets post-sovjetiske forandringer, verk om byens historie og arbeider om Euromajdan protestene i et historisk perspektiv (som henholdsvis Cybriwsky 2014a og Cybriwsky 2014b), så er det såvidt meg bekjent ingen som inngående har diskutert forholdet mellom Majdans form, historie, symbolikk og funksjon.

\footnotetext{
${ }^{4} \mathrm{Jeg}$ har benyttet meg av mye av det samme kvalitative kildematerialet som i min masteravhandling om Euromajdan (Hansen 2015).

${ }^{5}$ Lynch legger blant annet vekt på menneskers vanlige og mulige bevegelsesmønstre (paths); landemerker og punkter mennesker skal til, relaterer til eller drar gjennom (landmarks og nodes); ting som hindrer bevegelse (edges); og områder i byen med distinkt karakter (districts). Her er ikke disse termene brukt direkte, men de ligger likevel til grunn for analysen.

${ }^{6} \mathrm{Av}$ hensyn til respondentenes sikkerhet er navnene deres anonymisert og oppført i teksten i kursiv. Det gjelder imidlertid ikke den ukrainske fotojournalisten Oleksandr Klymenko, som har ønsket å framstå med fullt navn.
} 


\section{Byrommets posisjon og utforming}

Ukrainas hovedstad ligger sentralt i landet, mellom Polen i vest (440 km fra Kyiv) og Russland i øst $(300 \mathrm{~km})$. Selv om det er større avstander til områder som Donbas og Krimhalvøya (henholdsvis 600 og $550 \mathrm{~km}$ ) enn til for eksempel Hviterussland (95 km), gjør infrastruktur som vei, tog og elva Dnipro Kyiv til en mer sentral by enn noen annen i landet.

Ifølge legendene ble Kyiv grunnlagt $\mathrm{i}$ år 482, og Kievriket regnes som det historiske grunnlaget for de tre moderne nasjonene Ukraina, Hviterussland og Russland. Det var i Kyiv Kievriket i år 988 først skal ha bli kristnet, og byen er dermed viktig for flere ortodokse kirker. ${ }^{7}$ Noen av den ortodokse kristendommens mest hellige bygninger, blant annet Sofiakatedralen og grotteklosteret KyjevoPetsjerska Lavra, er plassert i byen. I tillegg til å være et viktig historisk og religiøst sentrum, finner man i Kyiv mange av Ukrainas viktigste politiske institusjoner, samt noen av landets eldste og mest prestisjefylte universiteter.

Uavhengighetsplassen ligger midt i Kyiv, mellom tre bakketopper, høyt oppe på den vestre (høyre) bredden av Dnipro. Seks små gater (Borysa Hrintsjenka, Provulok Tarasa Sjevtsjenka, Sofijivska, Mala Zjytomyrska, Mykhajlivska og Kostjolna) løper opp fra plassens nordvestre del (heretter NV-delen) mot byens historiske og religiøse sentrum på Starokyjivska og Zamokva-høydene. Fra den sydøstre delen av plassen (heretter SØ-delen) peker to gater (Instytutska og Arkhitektora Horodetskoho) oppover mot det politiske sentrum på Petsjerskhøyden. Her oppe ligger Presidentadministrasjonen, Verkhovna rada (parlamentet), Regjeringsbygget, Sentralbanken og flere partiers hovedkontorer. Den 1,3 kilometer lange hovedgaten Khresjtsjatyk går gjennom Uavhengighetsplassen på sin vei mellom Europaplassen i nordøst og Bessarabskyj i sør. Uavhengighetsplassen er stor, omtrent 370 meter lang og mellom 110 og 200 meter bred (avhengig av hvor og hvordan man måler). Khresjtsjatyk, med sine åtte kjørefelt og 60 meters bredde, fortau inkludert, er også en naturlig del av byrommet. Samlet kan plassen og gaten derfor romme hundretusenvis av mennesker. I området rundt Uavhengighetsplassen ligger det mange møtesteder, blant annet flere parker, store byrom og utdanningsinstitusjoner.

\section{Plass og byhistorie}

En måte å se Kyivs utvikling gjennom tidene er gjennom sentrumsplassens mange navn. Det var først på 1700-tallet området der Uavhengighetsplassen nå ligger ble bygget ut, men det var også her Ljadskyjporten - en av middelalderbyens tre innganger lå. Gjennom denne porten skal mongolene ha invadert Kyiv i 1240 og markert slutten på Kievriket. Fra midten av 1800-tallet vokste byen kraftig. Den lille

\footnotetext{
${ }^{7}$ Spesielt viktig er byen for: Den russisk-ortodokse kirke; Den ukrainsk-ortodokse kirke, som har hovedsete i Kyiv, men er underlagt Moskvapatriarkatet; Den ukrainsk-ortodokse kirke med eget patriarkat i Kyiv; Den ukrainske gresk-katolske kirke (denne er offisielt katolsk, men følger det bysantinske ritus); og Den ukrainske autokefale ortodokse kirke.
} 


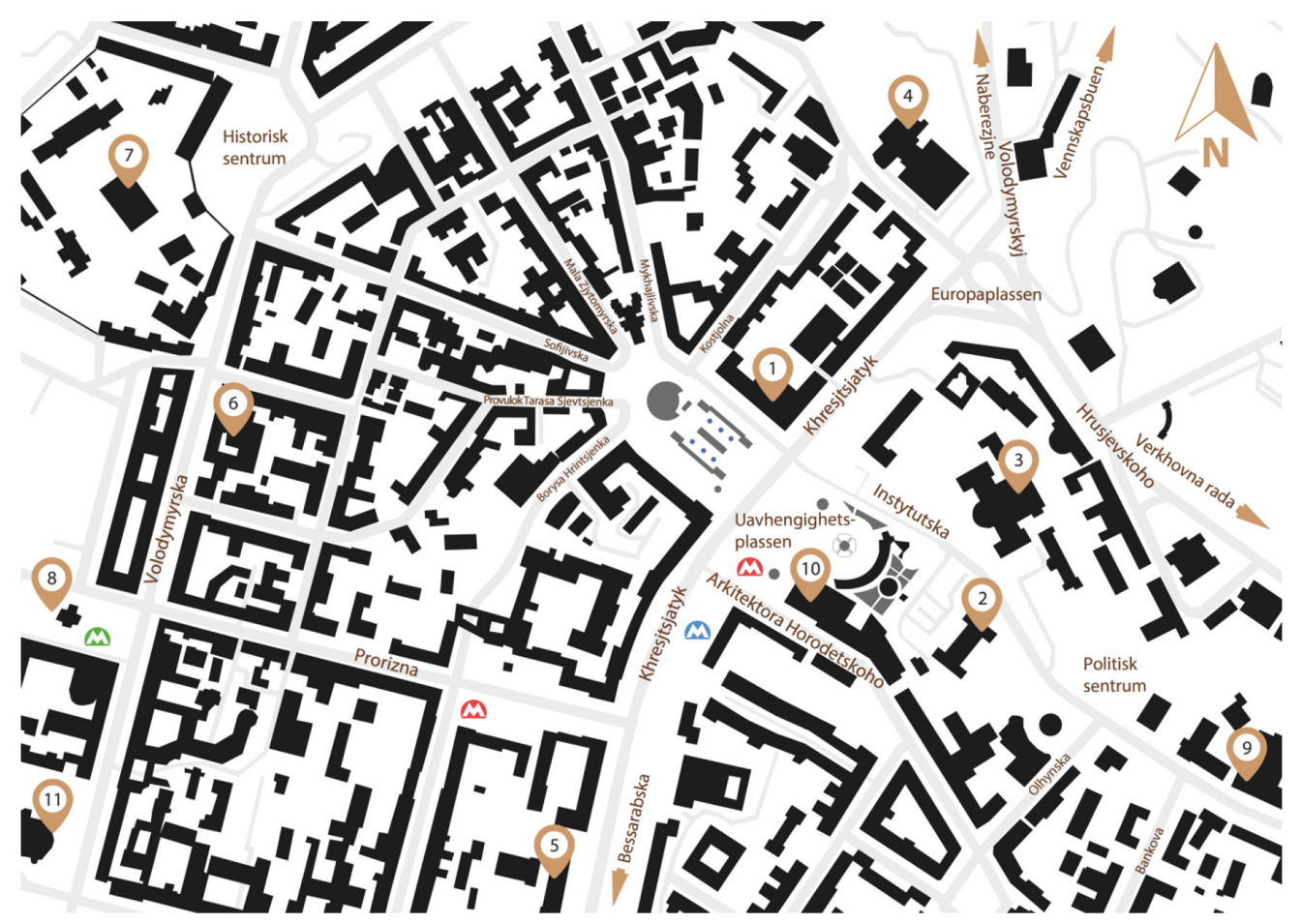

Bilde 1: Majdan sett ovenfra. 1: Fagforeningenes hus. 2: Hotell Ukraina. 3: Oktoberpalasset. 4: Ukrajinskyj dim. 5: Byadministrasjonen. 6: Sikkerhetstjenesten (SBU). 7: Sofiakatedralen. 8: Gullporten. 9. Nasjonalbanken. 10: Konservatoriet. 11: Operaen. Illustrasjon: Arve Hansen.

plassen ble først kalt Khresjtsjatykplassen i 1869 etter den tettbygde handelsgaten. Da bydumaen ble bygget i 1876 skiftet plassen navn til Dumaplassen (GUOKS u.d.).

Etter bolsjevikenes maktovertagelse i 1919 forandret plassens navn seg mange ganger. Først ble den hetende Sovjetunionens plass, og fra 1935 ble den kalt Kalininplassen etter den sovjetiske politikeren Mikhail Kalinin. Mellom 1941 og 1943 ble plassen kalt Nittende septembers plass, etter datoen for Nazi-Tysklands okkupasjon av byen, og da byen ble gjenerobret av den røde hær ble plassen igjen hetende Kalininplassen (GUOKS u.d.).

I forbindelse med Oktoberrevolusjonens 60-årsjubileum i 1977 ble byrommet renovert og fikk navnet Oktoberplassen. NV-delen som tidligere hadde vært godt trafikkert og som hadde mange fysiske hindringer, ble omstrukturert til et grønt, åpent parkområde med mindre trafikk og med gode muligheter for større folkesamlinger. I enden av SØ-delen ble det bygget et stort granittmonument til Lenin og Oktoberrevolusjonen (Hrysjtsjenko 2013: 86). Etter Sovjetunionens fall i 1991 skiftet plassen navn til Uavhengighetsplassen, som den fortsatt heter i dag.

Byrommets fasader viser også noen av forandringene byen har gått gjennom. Kun Oktoberpalasset (nå et kunstsenter) - på toppen av en stor gressbakke i østenden av plassen - og Konservatoriet står igjen fra før andre verdenskrig. Mangelen på bygninger fra før krigen vitner om ødeleggelsene byen og folket opplevde i krigsårene. 
Etter krigen gjenoppbygde Stalin byen i sovjetisk klassisistisk stil ved hjelp av krigsfangers slavearbeid: Khresjtsjatyk ble til et bredt sovjetprospekt og Kalininplassen ble byens sentrale torg - dumaen hadde brent ned under krigen og ble ikke gjenoppbygget. Bygningene langs Khresjtsjatyk og på NV-delen av Kalininplassen ble alle bygget i gul naturstein med samme, majestetiske design (sarkastisk kalt Stalins bløtkake[-stil] av byens borgere). ${ }^{8}$

Stalins død i 1953 førte imidlertid til en brå stans i denne arkitektoniske nyklassisismen. Khrusjtsjov forkastet de grandiose planene og fullførte gjenoppbyggingen i en svært forenklet form. Hotell Moskva (fra 2001 Hotell Ukraina) er et godt eksempel på denne forenklingen. Hotellet som står på toppen av bakken i enden av SØdelen var ment å bygges som en av Stalins vysotki (skyskrapere), men ble hurtig gjort ferdig, lavere enn planlagt og uten den klassiske dekoren. Plassens to største bygninger, Postbygget og Fagforeningenes hus, står også stilmessig i kontrast til hverandre. Postbygget er bygget i tradisjonell sovjetisk klassisisme, mens Fagforeningenes hus er postmoderne, toppet av et 24 meter høyt klokketårn - med digitale visere.

Etter Sovjetunionens fall gikk Kyiv gjennom en brå overgang til kapitalisme. På toppen av alle Uavhengighetsplassens bygninger er det nå store lysreklamer. Før Fagforeningenes hus ble totalskadd under Euromajdan, var nesten hele dets fasade dekket av enorme reklameplakater. På bakkeplan har banker, fastfood-kjeder og kiosker tatt over bybildet.

I løpet av vinteren 2000-01 startet en storstilt rekonstruksjon av byrommet, og et kjøpesenter ble bygget på Uavhengighetsplassen. Kjøpesenteret er to etasjer dypt og strekker seg under hele NV-delen. En seks meter høy glasskuppel i enden av plassen fører lys ned til senteret. I den andre, sørøstlige, enden av plassen, står en enorm speilglassfasade i tre etasjer. Det er kjøpesenterets andre del, plassert foran Hotell Ukraina. Kjøpesenteret ble sterkt kritisert for å skjemme Majdans utseende, og selv utbyggeren, Hari Korohodskyj, uttalte i 2007 at han var enig i kritikken (Fokus 2007). Parallelt med byggingen av kjøpesenteret ble det satt opp mange nye monumenter som framstiller Ukrainas historiske og mytiske figurer. Dette var en del av president Leonid Kutsjmas nasjonaliseringsprosjekt for å samle landet om en ny felles historieframstilling.

Hrysjtsjenko har skrevet om rekonstrueringen av byrommet og om hvordan plassen gikk fra å være et grønt samlingspunkt til et grått og uframkommelig område som har mistet mye av sin sjarm. Det er betegnende for måten Kutsjmas nasjonaliseringsprosjekt ikke ble spesielt populært i befolkningen, at Uavhengighetsmonumentet - byrommets mest kjente landemerke - ofte bare nevnes med tilnavn som «Stolpen», «Damen med kvisten» eller «Batman» (Hrysjtsjenko 2013: 86-87).

\section{Daglig bruk}

Majdans byrom - tross dets noe uryddige utforming - blir i det daglige brukt av svært mange mennesker. Khresjtsjatyk fungerer som den naturlige bilveien mellom

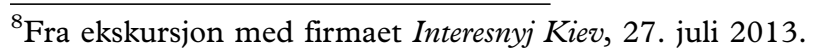




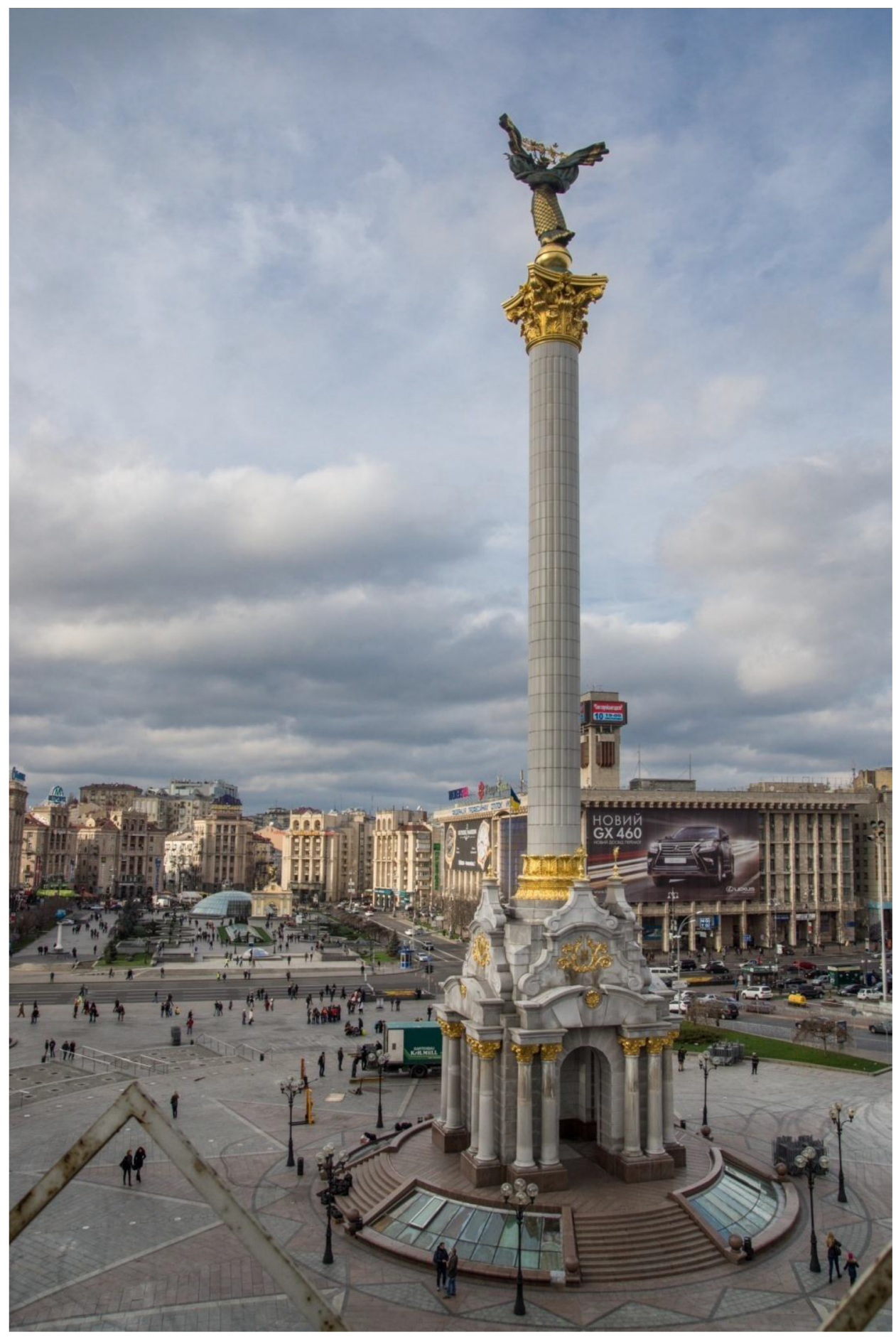

Bilde 2: Uavhengighetsmonumentet (eller Stolpen). Statuen er 62 meter høy og forestiller Berehynia - beskytteren, en kvinnelig ånd fra slavisk mytologi. Foto: Pedro J Pacheco CC BY-SA 4.0. 


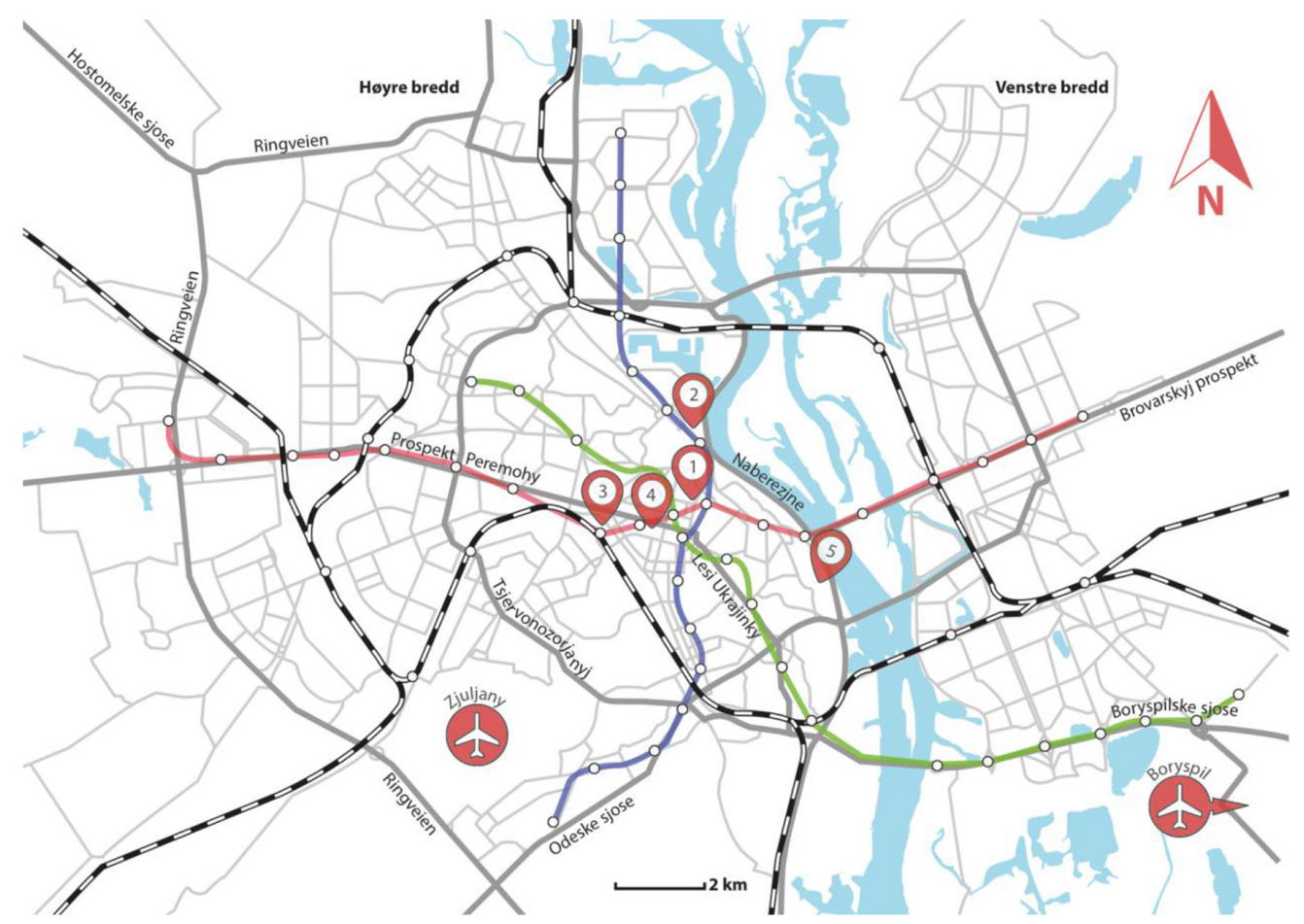

Bilde 3: Kyiv innenfor Ringveien. 1: Uavhengighetsplassen. 2: Kontraktova Plosjtsja. 3: Hovedtogstasjonen 4: Kyivs nasjonale universitet. 5: Grotteklosteret Kyjevo-Petsjerska Lavra. Illustrasjon: Arve Hansen.

flere viktige innfartsruter: Naberezjne - som går langs Dnipro på høyre bredd; Bulvar Tarasa Sjevtsjenka - en forlengelse av Prospekt Peremohy som er en viktig trafikkåre fra de vestlige delene av Kyiv til sentrum; og Lesi Ukrajinky som via Basejna går fra sydøst til sentrum. Alle er brede, tett trafikkerte veier. Instytutska, som krysser Khresjtsjatyk og går over til Mykhajlivska er også godt trafikkert og er en viktig vei for å komme fra det politiske sentrum og ut i byen.

Kyiv har tre t-banelinjer. Under Uavhengighetsplassen ligger overgangen mellom Uavhengighetsplassen stasjon på den røde linjen og Khresjtsjatyk stasjon på den blå linjen. Det er også kort gangavstand til Zoloti vorota stasjon («Gullporten») på den grønne linjen. Både buss, minibuss og trolleybuss har ruter over Uavhengighetsplassen, og det er omtrent 3,5 km til jernbanens sentralstasjon.

Det er også mange fotgjengere som benytter seg av byrommet. Uavhengighetsmonumentet har blitt et av områdets naturlige møtesteder for folk, enten man skal spasere $i$ en av parkene i sentrum eller shoppe i et av Kyivs stadig voksende antall kjøpesentre. Det ligger også mange kafeer, restauranter og uteplasser i området som tiltrekker seg mengder med mennesker i løpet av dagen og kvelden. I helga stenges Khresjtsjatyk for biltrafikk og blir gågate, og den fylles ofte med iskremkiosker, gatemusikanter, gjøglere og mye annet, hele veien mellom Majdan og Bessarabskyj. Blant turister er plassen et av Kyivs mest besøkte steder, ikke bare på grunn av dens 
historie, beliggenhet og arrangementer, men også fordi mange av byens hoteller er plassert på og rundt Majdan.

Siden byrommet er stort og sentralt plassert blir det også brukt i sammenheng med festivaler, konserter og offisielle merkedager. På Arbeidernes internasjonale kampdag (1. mai), Seiersdagen over Nazi-Tyskland (9. mai) og Uavhengighetsdagen (24. august) foregår det opptog og militære parader, og 1. desember hvert år settes det opp en stor nyttårsgran på plassen.

\section{Protestplass}

Rent praktisk er det mange fordeler ved å bruke Uavhengighetsplassen til protester og demonstrasjoner. De mange parkene, store byrommene og utdanningsinstitusjonene i kort gangavstand fra plassen, gjør at demonstrasjoner kan arrangeres samtidig på flere steder $\mathrm{i}$ byen og senere føres ned til Majdan når de er store nok til å fylle plassen. Parken foran Sjevtsjenko-universitetet, Kontraktova-plassen og St. Mikhailsplassen har ofte blitt brukt på denne måten, blant annet under den såkalte Revolusjonen på granitten i 1990 (se nedenfor), Oransjerevolusjonen i 2004-05 og Euromajdan i 2013-14.

Uavhengighetsplassen har blitt et naturlig møtested for forskjellige grupperinger og organisasjoner både fordi den rommer mange mennesker, og fordi det er kort avstand til det politiske sentrum. En protestleir på Majdan kan raskt organisere aksjoner for å reagere på politikernes handlinger. Under Euromajdan, for å ta et eksempel, reagerte demonstrantene på nye lover og at aktivister ble fengslet ved å arrangere demonstrasjoner foran blant annet Verkhovna rada og bydomstolen.

Siden mange mennesker av forskjellige grunner bruker Uavhengighetsplassen, blir en protest raskt lagt merke til og kan potensielt vokse fort. Kyivs posisjon som politisk sentrum og byens religiøse og historiske betydning langt utenfor landegrensene giør at en protest her snart får mye oppmerksomhet. Samtidig er de mange platåene over $\mathrm{S} \varnothing$-delen praktiske utkikkspunkter hvor medier og andre som ønsker å ta bilder av protestene får god oversikt over det som foregår på Majdan.

Det er likevel noen ulemper for protester i byrommet. Plassens ti innganger og store størrelse giør det lett for demonstranter å komme seg dit, men gjør også området sårbart for angrep fra politi og andre sikkerhetsmyndigheter. Dette gjelder hovedsakelig små demonstrasjoner. Store folkemengder har derimot vist seg svært vanskelig å rydde bort. Selv da militære kjøretøy og skarpe våpen ble brukt i februar 2014 klarte ikke myndighetene å rydde mer enn en brøkdel av Euromajdan.

Noe som imidlertid utgjør en utfordring for store protester er alle de fysiske hindringene som dukket opp på plassen etter rekonstrueringen av byrommet i 2000 . NV-delens mange gjerder, fontener og benker hindrer ferdsel på tvers av plassen, og giør at mennesker der både har lite handlerom og begrenset oversikt over det som foregår. SØ-delen er mer åpen, men Uavhengighetsmonumentet står i veien for at plassens naturlige fokalpunkt kan brukes til å sette opp en scene så alle kan se den. Derfor settes ofte protestenes scene tett opp mot Khresjtsjatyk, vendt mot SØ-delen og pressefotografenes utkikkspunkter, og med ryggen til NV-delen. 
Ulempene oppveies likevel av fordelene ved å arrangere protester på Uavhengighetsplassen. Og det er sannsynlig at plassens fysiske egnethet har vært en viktig faktor for at store protester der har blitt en suksess (blant annet Oransjerevolusjonen i 2004-05 og Euromajdan i 2013-14). De fysiske egenskapene forklarer imidlertid ikke alene hvorfor Majdan har blitt et så sterkt symbol i Ukraina eller hvilken funksjon Majdan har i samfunnet.

\section{Byrommets symbolikk}

Majdan Nezalezjnosti består av to ord: majdan og uavhengighet. Ordet majdan ble en del av det ukrainske språket under det mongolske åket fra midten av 1200-tallet, og stammer fra det middelpersiske og arabiske ordet ميدان (mæjdān [persisk], midān [arabisk]). Majdan betyr plass eller arena på middelpersisk; og størrelse, sfære eller sted for spill på arabisk (majdan 1989). På ukrainsk har man to ord for torg/åpent byrom: majdan og plosjtsja. En majdan er i motsetning til en plosjtsja en større arena med mange innløpende gater (Vasjanovytsj 2011).

Ordet majdan finnes ikke på russisk, hvor man kun har ordet plosjtsjad. Etter at Sovjetunionen kollapset i 1991 og Ukraina erklærte seg uavhengig, skiftet Oktoberrevolusjonens plass (plosjtsja) navn til Uavhengighetsmajdan. Det nye navnet symboliserer derfor ikke bare at Ukraina er et selvstendig land, men vektlegger samtidig at landet ikke er russisk.

I tillegg til navnet på plassen, som er et symbol på ukrainernes selvstendighet, er det noe folkelig med Majdan. I det tilsynelatende rotet man finner på Uavhengighetsplassen, bestående av monumenter, bygninger i forskjellige stiler, enorme reklamebannere og mye annet, er det mulig å finne symboler på store deler av byens og landets historie. I tillegg fungerer Fagforeningenes hus - den store hjørnesteinen på NV-delen av plassen - som et symbol på kampen for arbeidernes rettigheter. Ukrainas kulturelle liv er representert med Kunstsenteret og Konservatoriet på den andre siden. At Majdan ligger nedenfor de religiøse og politiske institusjonene, men likevel regnes som sentrum av Kyiv og Ukraina, forsterker betydningen av at Majdan tilhører folket.

\section{5 år med protest}

Den første store protesten i dette konkrete byrommet foregikk på Oktoberrevolusjonens plass i oktober 1990. Ukraina var som mange andre sovjetrepublikker herjet av dårlig økonomi, korrupsjon og utbredt varemangel, samt følgene av Tsjernobylkatastrofen i 1986. Gorbatsjovs perestrojka- og glasnost-reformer hadde gjort protester mulig, og to studentorganisasjoner fra Kyiv og Lviv organiserte en sultestreik på granitten foran Lenin-monumentet, kalt Revolusjonen på granitten (heretter Granittrevolusjonen). Studentene krevde blant annet at Ukraina skulle melde seg ut av Sovjetunionen, omvalg i parlamentet og at vernepliktige skulle slippe å tjenestegjøre i konfliktområder som Afghanistan eller Nagorno-Karabakh. Protestene som startet med noen hundre studenter vokste seg snart store, og da gruvearbeidere 
fra Donbas sluttet seg til protestene begynte myndighetene å reagere. Det viktigste Granittrevolusjonen oppnådde, etter 16 dagers sultestreik, var at Oleksandr Donij, lederen for studentorganisasjonen i Kyiv, fikk direktesendt taletid i Verkhovna rada, hvor han gjentok demonstrantenes krav, og vernepliktige ble lovet å få tjenestegjøre i Ukraina (Divaki production 2011).

Sovjetunionen opphørte å eksistere ett år etter Granittrevolusjonen. Likevel ble ikke alt bedre med den nye uavhengigheten. En brå overgang til det kapitalistiske systemet, ukontrollert privatisering og noen forhastede økonomiske beslutninger førte til inflasjon og varemangel (Morrison 1993: 686). I kjølvannet av den økonomiske krisen fulgte økt korrupsjon og kriminalitet. Tre rivaliserende oligarkklaner (Kyiv-klanen, Dnipropetrovsk-klanen og Donetsk-klanen) etablerte seg på 1990-tallet, og disse var ofte i en økonomisk, og i mange tilfeller også voldelig, konflikt med hverandre (Matuszak 2012: 13-15).

Ukrainas andre president, Leonid Kutsjma, fikk stoppet det økonomiske kaoset som hadde herjet under president Leonid Kravtsjuk. I løpet av sin første presidentperiode (1994-1999) stabiliserte han økonomien, fikk innført landets første grunnlov og oppnådde en stor vekst i middelklassen. I Kutsjmas andre periode (1999-2005) stoppet imidlertid den positive utviklingen, og oligarkene fikk mer makt enn før. Korrupsjonen steg og presidenten økte sensuren i massemediene (Dyczok 2006; Hansen 2015: 15-16).

I år 2000 kom president Kutsjma i sentrum av en stor skandale: Tre uker etter at den regimekritiske journalisten Heorhij Gongadze ble funnet torturert og halshugget $i$ en skog utenfor Kyiv, ble lydopptak fra presidentens telefon lekket av presidentens tidligere livvakt, Mykola Melnytsjenko. Opptakene skal ha vist at presidenten blant annet beordret drapet på Gongadze, at han drev med valgfusk og korrupsjon og at han stod bak en rekke andre kriminelle handlinger (Kuzio 2007: 42). Den såkalte kassettskandalen utløste «Ukraina uten Kutsjma»-protestene vinteren 2000-01, hvor tusenvis av demonstranter krevde presidentens avgang. Protestene slo seg først ned på Majdan, men den store ombyggingen av plassen, som er nevnt ovenfor, ble et påskudd for å tvinge protestleiren vekk fra Majdan. Demonstrantene ble nødt til å flytte til parken foran Sjevtsjenko-universitetet, hvor de ble i nesten tre måneder før teltleiren brutalt ble fjernet av opprørspolitiet i mars 2001. Cybriwsky (2014a: 167) hevder at myndighetene brukte arbeidene på Majdan den vinteren både for å fjerne protestene og for å bygge om plassen så den ble mindre egnet for store protester.

Til tross for de nye hindrene ble Uavhengighetsplassen likevel åstedet for Oransjerevolusjonen i 2004-05. Etter en dramatisk valgkamp mellom Kutsjmas kandidat, Viktor Janukovytsj, og tidligere statsbanksjef Viktor Jusjtsjenko, ble førstnevnte erklært som vinner. Jusjtsjenko hadde blitt forgiftet under valgkampen, men overlevde, og det var mange rapporter om valgfusk (Wilson 2005: 70-121). Den til da største protesten i Ukraina ble ledet av Jusjtsjenko og Julia Tymosjenko. Etter to måneder på Majdan, med til tider hundretusenvis av demonstranter, gikk myndighetene med på å endre grunnloven og en ny valgrunde. Jusjtsjenko vant det nye valget. 


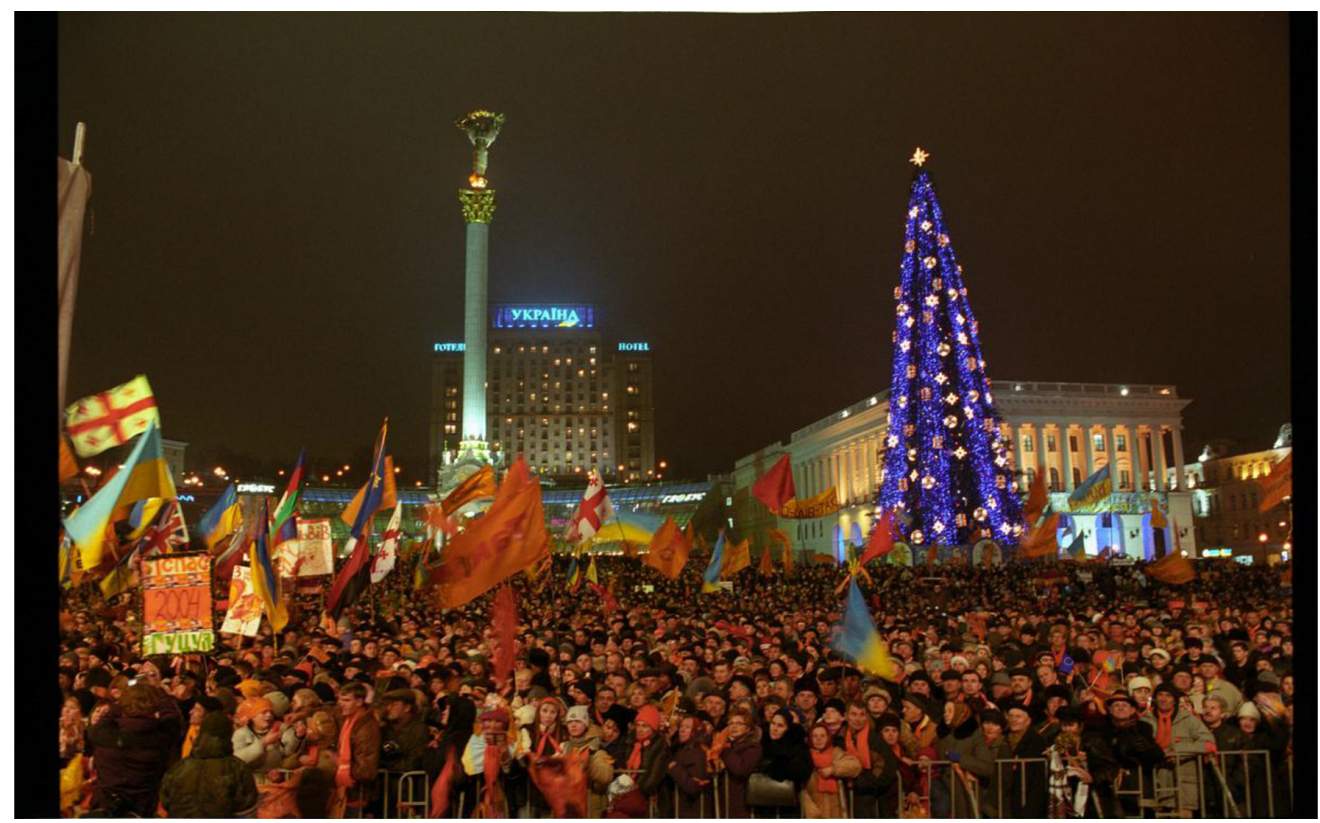

Bilde 4: Oransjerevolusjonen på Uavhengighetsplassen 2004. Foto: Oleksandr Klymenko.

Jusjtsjenko hadde gått til valg på å få gjennom reformer, fjerne korrupsjonen og løfte økonomien, men Jusjtsjenko og den nye politiske ledelsen ble en stor skuffelse. Presidenten slet med å få gjennomført de varslede reformene og klarte verken å samarbeide med parlamentet eller med Tymosjenko. Sistnevntes kritikk mot Jusjtsjenko ble stadig mer høyrøstet, og de to ble snart politiske fiender. I 2010, fem år etter at Jusjtsjenko ble president, hadde han fått til lite. Korrupsjonen hadde steget og verdien på den ukrainske hryvnjaen hadde falt med 38\% i forhold til dollaren (BBC 2009), fremdeles stod drapet på Gongadze uoppklart og oligarkene hadde stadig minst like mye makt. I presidentvalget i 2010 stilte Janukovytsj på nytt og vant mot Tymosjenko med 48,95\% mot $45,47 \%$ av stemmene. Jusjtsjenko gikk ut etter første runde med kun 5,5\% oppslutning (Kireev 2007).

Janukovytsj fikk snart kritikk fra mange hold. Han ble anklaget for å føre en unasjonal politikk (Kuzio 2012; Zik 2010), for å gjøre det vanskelig for små bedrifter (Hansen 2015: 19), for at korrupsjon og kriminalitet økte, og for en forverring i menneskerettighetssituasjonen (Zakharov 2014: 13-28, 161-173). Mange protester mot myndighetene ble arrangert på Majdan. Noen av de største var «Skattemajdan» i 2010, mot en økning av statens kontroll over små og mellomstore bedrifter; «Frihet til Julija»-demonstrasjonene ( $F u l i$ voli) i 2011, mot den strafferettslige forfølgelsen av Janukovytsj' rival Julija Tymosjenko; og Vradijivka-protestene, som etter en bortføring og brutal gjengvoldtekt av en kvinne i den lille byen Vradijivka, var rettet mot embetsmenn i rettssystemet - anklaget av demonstrantene for å beskytte en av de mistenkte politimennene (Hansen 2015: 19-20). 
Euromajdan var altså kun den siste av flere protester mot Janukovytsj og en av svært mange protester som har foregått på Majdan siden Ukraina ble selvstendig. Protestene beskrevet ovenfor omfatter bare noen av de mest kjente av disse, og det har blitt en form for tradisjon å gå ut på Majdan når man ønsker å protestere mot myndighetene. ${ }^{9}$ Siden Majdan samtidig kan assosieres med fire revolusjoner, har plassen også en revolusjonær symbolikk. Granittrevolusjonen, Oransjerevolusjonen og Euromajdan foregikk på Majdan, mens Oktoberrevolusjonen var navnet på plassen fram til 1991. Fotojournalisten Oleksandr Klymenko mener at navnet på Oktoberrevolusjonens plass var en av grunnene til at studentene i 1990 valgte den som åsted for Granittrevolusjonen. Den revolusjonære symbolikken har ikke blitt svakere etter at så mange demonstranter døde i sammenstøtene i februar 2014. De drepte demonstrantene presenteres i Ukraina som helter, samlet er de en del av «Himmelhundringen» (Nebesnja sotnja) - et symbol på ukraineres vilje til å dø for forandringer i landet.

Majdan er selvfølgelig ikke det eneste byrommet som kan brukes til protester i storbyen Kyiv. Byrommene på Sofiaplassen og St. Mikhailsplassen kan samlet romme mange mennesker. Sjevtsjenkoparken foran universitetet med samme navn har stor symbolsk verdi fordi dikteren Taras Sjevtsjenko (1814-61) regnes som en av Ukrainas viktigste opposisjonelle skikkelser. Parlamentsplassen foran Verkhovna rada ligger sentralt i forhold til politiske institusjoner. Alle disse byrommene kan og blir ofte brukt til demonstrasjoner, men som nevnt ovenfor benyttes disse i mindre grad og ofte i forbindelse med større protester på Majdan. Utforming og beliggenhet er nok en viktig grunn til at de ikke blir brukt så ofte (Hansen 2015: 37-38), men at Majdan har fătt en bredere symbolsk verdi er nok enda viktigere.

\section{Funksjon}

Så hvilke funksjoner har Majdan for det ukrainske samfunnet? Mange av respondentene mine forteller at de oppfatter Majdan som en viktig del av det politiske systemet. Hanna, en aktiv internettaktivist, mener at Majdan oppstod som en reaksjon på korrupsjonen i det politiske systemet, og nå har blitt en bevegelse for å bli kvitt denne:

Vår politikk er så til de grader korrumpert at Majdan har blitt en nødvendighet. (...)
Majdan det er en spontan aksjon, protest, refleks (...). Men etterhvert oppstod et felles
mål: å bli helt kvitt det korrupte systemet. Man kan si at dette er en sosial bevegelse mot
korrupsjon eller gjenferdet etter Sovjetunionen. ${ }^{10}$

Når jeg spør respondentene hvilken funksjon de mener Majdan har, sammenligner flere av dem Majdan med forskjellige politiske institusjoner. Både fotojourna-

\footnotetext{
${ }^{9}$ I løpet av mine to bostedsopphold i Kyiv og hyppige reiser til byen har det tilsynelatende «alltid» foregått eller vært planlagt protester på Uavhengighetsplassen.

${ }^{10}$ Nasja polityka nastilky korumpovana, (. . .) sjtsjo nam prosto neobkhidnyj Majdan. (...) Majdan - tse spontanna aktsija, protest, refleks (...). Ale zhodom zjavylas spilna meta - povnistju zminyty korumpovanu systemu. Mozjna skazaty, sjtsjo tse sotialnyj rukh proty koruptsiji abo pryzraku Radjanskoho Sojuzu.
} 
listen Oleksandr Klymenko og lokalhistorikeren Serhij, som begge har sett flere protester på plassen gjennom tidene; og Stanislau - en hviterussisk aktivist som kom for å støtte Euromajdan, kaller plassen for en form for folkeparlament hvor man drar for å ordne opp i problemer. Serhij sammenligner Majdan med to former for folkestyrte forsamlinger:

(...) ordet Majdan har bare blitt betydningen på en eller annen form for aksjon med mange mennesker. Som en form for det gammelrussiske fenomenet vitsje. Eller som det norske ordet ting. Det vil si en folkesamling som tar en eller annen viktig avgiørelse [mine uthevinger]. ${ }^{11}$

Den amerikanske historieprofessoren Timothy Snyder trekker på sin side en parallell fra Majdan til den greske agoraen:

(...) a maidan now means in Ukrainian what the Greek word agora means in English: not just a marketplace where people happen to meet, but a place where they deliberately meet, precisely in order to deliberate, to speak, and to create a political society (Snyder 2014).

Flere andre, blant annet den ukrainske journalisten og bloggeren Volodymyr Zolotorjov, legger også vekt på Majdan som et sted for diskusjon: «Majdan, det er sosial trening for felles handling og felles kommunikasjon. Ukrainere lærer seg å bli et samfunn, samhandle og kommunisere» ${ }^{12}$ (Zolotorjov 2013).

Det er selvfølgelig mulig å stille kritiske spørsmål ved påstandene om at Majdan er som et ting eller en agora. Under Euromajdan ble den politiske situasjonen og hva som må gjøres selvfølgelig diskutert av de ulike grupperingene, men likevel var det få tegn under mine befaringer på at Majdan var et sted hvor diskusjon sto i sentrum. Det var ikke åpent for at myndighetene eller andre meningsmotstandere kunne delta i debattene på Majdan, og de frammøtte var som regel enige om hva og hvem de var mot, selv om det til tider var uenighet om virkemidlene. Dermed virket Majdan mer som et sted for aksjon enn for demokratisk diskusjon.

Likevel er det her kanskje mindre relevant å spørre i hvilken grad Majdan fungerer som et folkeparlament, og viktigere å spørre hvilken funksjon Majdan har i Ukraina. For hvis det eksisterer et sted man stadig går for å aksjonere mot myndighetene, så har det en viktig funksjon: Protester dukker opp på Majdan når det er stor misnøye med en sak og ukrainere ikke er fornøyd med hvordan myndighetene behandler saken. Derfor er det mulig å se på Majdans funksjon som en form for sikkerhetsventil for det ukrainske samfunnet. Et sted ukrainere føler de har mulighet til å påvirke politikken direkte, om presset blir for stort.

Alle kan okkupere Majdan, og forskjellige grupper og sjikt av befolkningen har startet protester på plassen. Under Granittrevolusjonen i 1990 og Euromajdan i

\footnotetext{
${ }^{11}$ (...) slovo Majdan prosto stalo oznatsjat imenno kakuju-to mnogoljudnuju aktsiju. Kak tipa drevnorusskoje javlenije vetsje. Ili podobnoje $\mathrm{k}$ norvezjskomu slovu ting. To jest eto narodnoje sobranije, kotoroje prinimajet kakoje-to resjenije vazjnoje.

${ }^{12}$ «Majdan - eto sotsialnaja praktika vzaimo-dejstvija, so-obsjtsjenija. Ukraintsy utsjatsja byt obsjtsjestvom, vzaimo-dejstvovat i so-obsjtsjatsia» (sic).
} 
2013-14 var det studenter som startet protestene, men protester har også blitt startet av politikere, som under Oransjerevolusjonen i 2004-05; forretningsmenn, som under Skattemajdan i 2010; og mennesker fra lokale tettsteder, som under Vradijivka-protestene i 2013. Det er imidlertid appelleringsevnen til den konkrete saken som avgjør om andre grupper av samfunnet slår seg til og, som de sier i Ukraina, «en ny Majdan begynner» (novyj Majdan potsjynaetsia).

\section{Konklusjoner}

Jeg spurte innledningsvis hva det er som gjør Uavhengighetsplassen til Ukrainas protestplass, hva plassen symboliserer, og hvilken funksjon Majdan har.

Protester har lenge vært en del av det politiske bildet i Ukraina. I løpet av minst 25 år med sosial misnøye og 30 år med økonomiske problemer, har tilliten til de politiske institusjonene i landet blitt svekket. Korrupsjon og kriminalitet i landets lille elite har ført til at mange ukrainere oppfatter politikere som representanter kun for sine egne interesser - ikke folkets. Skuffelsene etter Oransjerevolusjonen har ført til at denne oppfatningen gjelder alle politikere, enten de er i parlamentet eller en del av opposisjonen. Når folket mener politikerne gjør en dårlig jobb med å ivareta deres interesser, trekker de ut på Uavhengighetsplassen. Til tross for forsøk på starten av 2000-tallet på å gjøre byrommet mindre tilgjengelig for store folkemengder, har området likevel blitt stedet folk samles for å protestere.

Uavhengighetsplassen er fysisk godt egnet som protestplass. Den ligger strategisk plassert mellom andre møtesteder i byen, noe som gjør at demonstrasjoner kan arrangeres på flere steder samtidig og føres ned til Majdan, og den er kort vei fra politisk sentrum på Petsjersk-høyden. Det samlede byrommet på Majdan og Khresjtsjatyk er også stort og åpner for at store folkemengder kan demonstrere samtidig. De mange innfartsårene og plassinngangene gjør at det er lett å komme seg til Majdan, og myndighetene sliter med å kontrollere hva som foregår der. Plassens konstruksjon gjør at det er svært vanskelig å rydde folk vekk fra plassen, om de har fått anledning til å slå seg ned.

Uavhengighetsplassen er også symbolsk og kulturelt egnet for protester. Navnet symboliserer en avstand til Russland, da begge ordene majdan og uavhengighet knyttes til uavhengigheten i 1991. Plassens posisjon er nedenfor de politiske, religiøse og historiske sentrene, men likevel sentrum av byen. Det gjør at byrommet har en spesiell folkenær symbolikk. Symbolikken forsterkes av Arbeiderforeningenes hus, de kulturelle bygningene, og all lokalhistorien - $\mathrm{i}$ form av bygninger og monumenter. Siden Majdan samtidig assosieres med fire vellykkede revolusjoner, hvorav tre kan kobles direkte til plassen, minnes byen og landets borgere om mulighetene et slikt byrom gir dem.

Det er til Majdan ukrainere drar for å bli hørt når politikken ikke fungerer, og Majdan kan ses på som en form for sikkerhetsventil - et sted hvor folket kan gå ut og kaste ledelsen, om de går for langt vekk fra folkets ønske. At det har vært så mange protester på Majdan sier både noe om hvor viktig denne sikkerhetsventilen er, og hvor vanskelig det er å reformere det ukrainske samfunnet. Målet med de fleste 
protestene har vært å fjerne det korrupte lederskapet, men det er ikke gitt at en ny ledelse fører til et nytt og reformert samfunn.

Ukrainas nåværende politiske ledelse kjenner betydningen av Majdan. Politikerne fikk posisjonene sine etter at president- og parlamentsvalgene i 2014 hadde blitt framskyndt på grunn av revolusjonen. Når så Porosjenko-administrasjonen blir truet med en ny Majdan vet de hva det kan bety. I et klima herjet av krig og ustabilitet, men samtidig mange reformer, vil det være interessant å se hvordan Majdan vil bli brukt i tiden framover.

\section{Om artikkelen}

Jeg vil gjerne takke Instituttet for historie og religionsvitenskap ved UiT Norges arktiske universitet, som ga meg stipend for å utarbeide denne artikkelen. En stor takk går også til Oleksandr Klymenko som tillot meg å bruke fotografiet hans fra Oransjerevolusjonen.

\section{Litteratur}

BBC (2009) «Ukraine’s Economy 'to Shrink 9\%’». 7. april. Tilgjengelig på http://news.bbc.co.uk/2/hi/business/ 7988196.stm. Lesedato 13. april 2015.

Cybriwsky, Roman (2014a) Kyiv, Ukraine. Amsterdam: University Press.

Cybriwsky, Roman (2014b) «Kyiv's Maidan: from Duma Square to Sacred Space». Eurasian Geography and Economics 55 (3): 270-285.

Divaki production (2011) «16 dniv. Revolutsija na hraniti. (povna versija)». Tilgjengelig på www.youtube.com/ watch?v=7NY_icyX2Tg. Lesedato 20. januar 2016.

Dyczok, Marta (2006) «Was Kuchma's Censorship Effective? Mass Media in Ukraine Before 2004». EuropeAsia Studies 58 (2): 215-238.

Fokus (2007) «Stilnyj biznesmen Harri Korogodskij stroit torgovyje tsentry v Kijeve, no odezjdu i otsjki pokupajet za granitsej». 14. desember. Tilgjengelig på http://focus.ua/news/13931. Lesedato 10. oktober 2015.

Göle, Nilüfer (2013a) «Public Space Democracy». Transit 44. Tilgjengelig på www.eurozine.com/pdf/2013-0729-gole-en.pdf. Lesedato 15. august 2015.

Göle, Nilüfer (2013b) «Gezi - Anatomy of a Public Square Movement». Insight Turkey 15 (3): 7-14. Tilgjengelig på http://file.insightturkey.com/Files/Pdf/it15_03_2013_gole.pdf. Lesedato 15. august 2015.

GUOKS u.d. «Majdan Nezalezjnosti (XIX-XX st.)». Tilgjengelig på http://guoks.gov.ua/monuments/ monuments/maydan-nezalezhnosti-hih-hh-st. Lesedato 25. januar 2016.

Hammond, John L. (2013) «The Significance of Space in Occupy Wall Street». Interface 5 (2): $499-524$. Tilgjengelig på www.interfacejournal.net/wordpress/wp-content/uploads/2013/11/Interface-5-2-Hammond.pdf. Lesedato 15. august 2015.

Hansen, Arve (2015) Majdan 2013-2014: Plassen, protestene, drivkreftene. Mastergradsavhandling, Universitetet i Tromsø. Tilgjengelig på http://hdl.handle.net/10037/7700. Lesedato 13. mai 2015.

Helseministeriet i Ukraina (2014) «Informatsija pro postrazjdalykh u sutytsjkah v tsentri Kyjeva stanom na 06.00 hod. 23 lutoho 2014 roku». 23. februar. Tilgjengelig på www.moz.gov.ua/ua/portal/pre_20140223_ b.html. Lesedato 10. oktober 2015.

Hershkovitz, Linda (1993) «Tiananmen Square and the Politics of Place». Political Geography 12 (5): $395-420$.

Hrysjtsjenko, M. V. (2013) «Publitsjnyj prostir Kyjeva jak seredovysjtsje projavu postkomunistytsjnykh transformatsij ukrainskoho suspilstva. Psikholohija v Ukrajini ta za kordonom» i Materialy mizjnarodnoji naukovo-praktytsjnoji konferentsiij ( $m$. Tsjernihiv, 8-9 lystopada 2013 roku): Kherson: Vidavnitsjij dim «Helvetika» (82-88). Tilgjengelig på http://molodyvcheny.in.ua/files/conf/psy/01 nov2013/01 nov2013.pdf. Lesedato 15. september 2014.

Inceoglu, Irem (2014) "The Gezi Resistance and its Aftermath: A Radical Democratic Opportunity?». Soundings: A fournal of Politics and Culture 57 (1): 23-34. 


\section{ARVE HANSEN}

Inceoglu, Irem (2015) «Encountering Difference and Radical Democratic Trajectory: An Analysis of Gezi Park as Public Space». City 19 (4): 534-544.

Kireev, Alex (2007) «Ukraina. Prezidentskie vybory 2010. Elektoralnaja geografija 2.0». Tilgjengelig på www. electoralgeography.com/new/ru/countries/u/ukraine/ukraina-prezidentskie-vybory-2010.html. Lesedato 10. oktober 2015.

Kuzio, Taras (2007) "Oligarchs, Tapes and Oranges: 'Kuchmagate' to the Orange Revolution». Fournal of Communist Studies and Transition Politics 23 (1): 30-56.

Kuzio, Taras (2012) «2012 Parliamentary Elections in Ukraine». Center for Strategic and International Studies. Tilgjengelig på https://itunes.apple.com/no/podcast/2012-parliamentary-\%20elections/id383698 245 ? $\mathrm{i}=123419448 \& \mathrm{l}=\mathrm{nb} \& \mathrm{mt}=2 @$. Lesedato 10. desember 2014.

Lee, Nelson, K. (2009) «How is a Political Public Space Made? - The Birth of Tiananmen Square and the May Fourth Movement». Political Geography 28 (1): 32-43.

Lopes de Souza, Marcelo \& Barbara Lipietz (2011) «The 'Arab Spring' and the City: Hopes, Contradictions and Spatiality». City 15 (6): 618-624.

Lynch, Kevin (1960) The Image of the City. Cambridge: MIT Press.

majdan (1989) O.S. Melnytsjuk, V.T. Kolomijets, V.H. Skljarenko, T.B Lukinova \& O.B. Tkatsjenko (red.) Etymolohitsjnyj slovnyk ukrajinskoji movy. Bind 3. Kyiv: Naukova dumka.

Matuszak, Slawomir (2012) «The Oligarchic Democracy: The Influence of Business Groups on Ukrainian Politics». OSW Studies 42. Tilgjengelig på http://aei.pitt.edu/58394/. Lesedato 17. desember 2014.

Morrison, John (1993) «Pereyaslav and After: the Russian-Ukrainian Relationship». International Affairs 69 (4): 677-703.

Norsk språkråd (2014) «Ukraina». Tilgjengelig på www.sprakradet.no/Vi-og-vart/hva-skjer/Aktuelt-ord/ Ukraina/. Lesedato 8. oktober 2015.

Norsk språkråd (u.d. a) «VL 6.2.05 Transkripsjon av russisk». Tilgjengelig på www.sprakradet.no/upload/ Rettskriving\%20og\%20ordlister/russ.pdf. Lesedato 13. januar 2014.

Norsk språkråd (u.d. b) «VL 24.10.6 Transkripsjon av ikke-russisk kyrillisk». Tilgjengelig på www.sprakradet. no/localfiles/9261/kyrillur.pdf. Lesedato 13. januar 2014.

Örs, İlay Romain (2014) "Genie in the Bottle Gezi Park, Taksim Square, and the Realignment of Democracy and Space in Turkey». Philosophy E Social Criticism 40 (4-5): 489-498.

Parkinson, John R. (2012) Democracy and Public Space: The Physical Sites of Democratic Performance. Oxford og New York: Oxford University Press.

Snyder, Timothy (2014) «Fascism, Russia, and Ukraine». The New York Review of Books. Tilgjengelig på www.nybooks.com/articles/archives/2014/mar/20/fascism-russia-and-ukraine/. Lesedato 25. mars 2014.

Terra Dignitas (2015) «Pro konkurs». Tilgjengelig på http://terradignitas.kga.gov.ua/pro-konkurs. Lesedato 20. juli 2015.

UN News Centre (2015) «Despite Less Fighting, Eastern Ukraine Still 'Highly Flammable,' UN Reports, as Death Toll Tops 9,000». 9. desember. Tilgjengelig på www.un.org/apps/news/story.asp?NewsID=52771\#. VpylCYQe7dk. Lesedato 18. januar 2016.

UNHCR (2015a) «Ukraine: 2015 UNHCR Subregional Operations Profile - Eastern Europe». Tilgjengelig på www.unhcr.org/cgi-bin/texis/vtx/page?page=49e48d4d6\&submit=GO\#. Lesedato 18. januar 2016.

UNHCR (2015b) «Ukraine Situation: UNHCR Operational Update. 2-24 December 2015». Tilgjengelig på www.unhcr.org/5614d3fb9.html. Lesedato 18. januar 2016.

Vasjanovytsj, Anatolij (2011) «'Plosjtsja' i 'majdan'». Tilgjengelig på http://firstua.com/uk/video/program/ zapamjatay/2011/02/18/2149. Lesedato 18. oktober 2015.

Wilson, Andrew (2005) Ukraine's Orange Revolution. New Haven: Yale University Press.

Zakharov, Yevhen (red.). (2014) Human Rights in Ukraine - 2013. Ukrainian Helsinki Human Rights Union. Kharkiv: Prava Ludyny.

Zik (2010) «1932-1933 Genocide in Ukraine was Invented by Foreign Historians, Tabachnyk Says». 1. september. Tilgjengelig på http://zik.ua/en/news/2010/09/01/243009. Lesedato 3. april 2015.

Zolotorjov, Volodymyr (2013) «O polze majdanov». Kontrakty.ua 28. november. Tilgjengelig på http:// kontrakty.ua/article/70358/. Lesedato 16. juni 2014. 